\title{
TEKANAN PENDUDUK TERHADAP LINGKUNGAN DAN SUMBER DAYA LAHAN/PERAIRAN DI WILAYAH PESISIR SERTA ALTERNATIF PENANGANANNYA
}

\author{
Zahri Nasution $^{1)}$ dan Mas Tri Djoko Sunarno ${ }^{2)}$ \\ 1) Peneliti pada Balai Besar Riset Sosial Ekonomi Kelautan dan Perikanan, Jakarta \\ 2) Peneliti pada Pusat Riset Perikanan Tangkap,Jakarta. \\ Teregristrasi I tanggal: 19 Januari 2009; Diterima setelah perbaikan tanggal: 22 Mei 2009; \\ Disetujui terbit tanggal: 1 Juni 2009
}

\begin{abstract}
ABSTRAK
Tekanan penduduk terhadap wilayah pesisir seperti pembuangan limbah, sampah rumah tangga, industri, dan plastik terus berlangsung, terutama di wilayah padat penduduk. Tulisan ini menguraikan akar-akar penyebab degradasi lingkungan yang berperan di suatu area tetap dan alternatif penanggannya. Hasil kajian di kecamatan pesisir dalam Kabupaten Indramayu, Jawa Barat menunjukkan bahwa kemiskinan atau pra sejahtera teramati di masyarakat pesisir. Penyebabnya antara lain adalah ketatnya persaingan pememanfaatan sumberdaya lahan/perairan, tingginya pertumbuhan penduduk, dan peningkatan penggunaan teknologi penangkapan ikan yang merusak sumberdaya ikan dan pembukaan lahan tambak. Tingginya pertumbuhan penduduk mengakibatkan tingginya persaingan pemanfaatan sumberdaya lahan/perairan sehingga terbentuk hubungan sosial patron klien. Lingkungan pemukiman tidak baik akibat kepadatan penduduk perlu ditata. Beberapa alternatif penanganannya adalah penurunan tingkat kelahiran, pengorganisasian kelompok nelayan secara aktif dalam pembuatan aturan pemanfaatan sumber daya perikanan laut, pembatasan izin masuk wilayah penangkapan terutama untuk alat tangkap tidak selektif dan bermotor, dan penyediaan alternatif sumber pendapatan di luar perikanan.
\end{abstract}

KATAKUNCl: tekanan penduduk, wilayah pesisir, sumberdaya lahan/ perairan

ABSTRACT: People presures on environment and land/waters resources in coastal area and its alternative solution. By: Zahri Nasution and Mas Tri Djoko Sunarno.

People pressures in coastal area such as waste exile of housing, industries and plastics exist continously. This paper described some roots causing environmental degradation playing in a fix area and their alternative solution. The observation in coaltal area of Distric Indramayu, West Java showed that poority or pra walfare was observed. It was caused by high competation in utilizing land/waters and high people growth, increasing use of fishing technology damaging fish resources and opening brackish water pond. High people growth caused increasing in utilizing resources of land/waters in coastal area so that client social patron existed. Bad environmental residence as a result of people density should be well organized. Some alternative solution suggested are declining natality rate, organizing fisher group in reguliting marine fiheries resource plan, limitation of enter pemit to fishing area, espicially for purse seine as well as providing an alternative source income out of fisheries.

KEYWORDS: people preasure, coastal area, waters/land resources

Kosrespondensi penulis:

Jl. Pasir Putih I, Ancol Timur-Jakarta 14430, Telp. (021) 64711940, Fax. (021) 6402640 


\section{PENDAHULUAN}

Pesisir merupakan salah satu wilayah yang sangat kompleks, baik ditinjau dari aspek ekologi maupun sosial ekonomi. Interaksi antara daratan dan lautan menjadikan pesisir sebagai suatu wilayah yang sangat penting bagi berbagai bentuk kehidupan di darat dan laut, termasuk manusia (Idris, 2003). Bagi sektor kelautan dan perikanan, pesisir dipandang sebagai wilayah paling produktif yang mudah diakses oleh manusia. Ikan dan berbagai makanan dari laut lainnya telah menjadi bahan makanan penting bagi manusia. Di samping itu, kegiatan perikanan budidaya, baik di laut maupun tambak, di wilayah pesisir dan industri pengolahan hasil perikanan menghidupi masyarakat pesisir.

Tekanan terhadap wilayah pesisir terus berlangsung secara alami (Idris, 2003). Angin dan ombak menggerakkan berbagai material di pantai sehingga mengubah bentangan lahannya. Hal dramatis terjadi pada saat badai yang membawa angin dan ombak dengan kekuatan besar sehingga dapat mengubah segala bentangan alam dalam waktu sekejap.

Keberadaan manusia di pesisir adalah salah satu bentuk dari tekanan itu sendiri. Kepadatan penduduk dapat memberikan tekanan bagi wilayah pesisir. Penggunaan sumberdaya yang terbatas oleh banyak orang dapat mengakibatkan terlampauinya daya dukung wilayah tersebut. Jumlah dan kepadatan populasi manusia di wilayah pesisir akan bertambah secara dramatis selama musim liburan. Manusia, baik yang tinggal secara tetap maupun sementara, memerlukan makanan, akomodasi, dan hiburan.

Tambahan, pembangunan fasilitas perumahan, hotel, resort, rumah makan, pusat bahan bakar, pusat perbelanjaan, warung, cottage banyak ditemui di wilayah pesisir Indonesia, khususnya di pusat wisata (Idris, 2003). Pembangunan fasilitasfasilitas tersebut dapat menambah tekanan terhadap ekosistem atau memicu dampak negatif. Sebagai contoh, penambahan area untuk jalan dan bangunan dapat meningkatkan aliran air permukaan di sekitar wilayah pesisir. Pembangunan infrastruktur seringkali juga mengubah secara alami lahan yang sudah ada seperti hutan bakau, lahan basah, dan lahan pantai.

Tekanan manusia terhadap wilayah pesisir mencakup pembuangan limbah, sampah rumah tangga, industri, dan plastik, terutama yang padat penduduknya. Dampak dari kegiatan manusia terhadap wilayah pesisir adalah sangat luas dan bersifat jangka panjang. Aktivitas manusia juga dapat mempengaruhi proses alami di pesisir dan mengganggu kemampuan ekosistem dalam menjaga keseimbangan dan keberlanjutan fungsinya. Kejadian tangkap lebih yang terjadi di perairan pesisir akan mengancam keberlanjutan ekosistem laut dan pesisir. Tulisan ini mengemukakan bagaimana tekanan penduduk di wilayah pesisir terhadap lingkungan dan sumber daya lahan/perairan serta alternatif penanganan masalahnya.

\section{KERANGKA TEORI DAN MODEL ANALISIS}

\section{Teori Kependudukan dan Lingkungan}

Malakah ini menggunakan dua pendekatan dalam mempelajari penduduk di wilayah pesisir, yaitu pendekatan demografi dan pendekatan kependudukan. Menurut Yusuf (2000), pendekatan demografi adalah suatu pendekatan yang mempelajari penduduk dengan mempelajari tentang jumlahnya, ciri-cirinya seperti umur dan jenis kelamin, status perkawinan, pendidikan dan pekerjaan, serta distribusi 
tempat tinggalnya. Selanjutnya, perubahan jumlah, ciri serta distribusi tersebut dapat disebabkan oleh perubahan kelahiran (fertilitas), kematian (mortalitas), dan perpindahan penduduk (migrasi).

Pendekatan kependudukan berarti mempelajari penduduk terkait dengan kebutuhan hidupnya seperti penduduk dengan pangan dan sandang, penduduk dengan pemukiman, penduduk dengan pendidikan dan pekerjaan, penduduk dengan kesehatan, dan masalah lingkungan (Yusuf, 2000). Pada umumnya, pemahaman terkait dengan kependudukan diperlukan pengetahuan demografi. Pengetahuan demografi ini diperoleh dari informasi melalui sensus, registrasi vital, dan survei penduduk.

Beberapa teori yang berkembang terkait dengan hubungan antara kependudukan dan lingkungan dapat dibedakan menjadi berbagai perspektif, yaitu perpektif IImu Ekonomi Neoklasik, Ilmu Pengetahuan Alam, Ekonomi Politik/Ketergantungan, dan Perspektif Kombinasi (Orians \& Skurmanich, 1997). Tulisan ini menggunakan perspektif kombinasi yang berpandangan bahwa ada sejumlah akar penyebab degradasi lingkungan yang berperan pada suatu area yang tetap (Orians \& Skurmanich, 1997). Contohnya adalah kemiskinan, hubungan sosial, distorsi ekonomi dan atau kebijakan politik, dan polusi atau teknologi yang tidak tepat. Oleh karena itu, pertumbuhan populasi bukan merupakan akar permasalahan, tetapi gabungan semua itu. Berdasarkan perspektif ini, untuk meyakinkan adanya perlindungan terhadap lingkungan, diperlukan identifikasi kasus per kasus untuk mencari penyebab dominan dari degradasi yang terjadi. Pengontrolan pertumbuhan populasi merupakan upaya pengurangan terhadap dampak lingkungan hingga pada tingkat tertentu.

\section{Model Keterkaitan Manusia dan Lingkungan}

Model keterkaitan antara manusia dan lingkungan menjelaskan dan mengevaluasi bagaimana berbagai populasi atau atribut lingkungan saling mempengaruhi. Saat ini, suatu gambaran mengapa terjadi degradasi lingkungan, secara bersama-sama dapat dilakukan dengan memperhatikan hal-hal yang berkaitan dengan faktor pertumbuhan dan distribusi penduduk, perubahan teknologi, perubahan tata guna lahan, kondisi ekonomi, kelembagaan, kebijakan, dan kebudayaan yang semuanya menjadi penting untuk meningkatkan atau menurunkan degradasi tersebut.

Menurut Orians \& Skurmanich (1997), ada dua model dalam mencermati keterkaitan antara penduduk dan lingkungan, yaitu model POET dan model IPAT. Setiap model memberikan pengertian hubungan atau keterkaitan antara penduduk dan lingkungan. Setiap model mempunyai penekanan tersendiri tergantung maksud detail dan tingkat kedalaman kajian. Model POET menggunakan pendekatan ekologi manusia berdasarkan kerangka kerja perluasan dari hubungan antara manusia, ekologi dan sosiologi. Dalam hal ini, P adalah populasi, $O$ adalah organisasi, $E$ adalah lingkungan, dan T adalah teknologi.

Model POET memberikan pengertian bahwa suatu hubungan populasi dengan lingkungan, tidak hanya menimbang tingkat populasi, tetapi juga organisasi sosial dan tipe teknologi yang digunakan. Untuk itu, pengorganisasian sosial dan teknologi menjadi media yang berpengaruh positif atau negatif pada suatu populasi terhadap lingkungan. Sebaliknya, pengorganisasian sosial dan teknologi menjadi media bagaimana manusia dipengaruhi lingkungan. Dalam model POET, interaksi manusia dan lingkungan adalah dua arah. 
Konsep Model IPAT prinsipnya seperti model POET, tetapi lebih dikembangkan dengan menjelaskan hubungan matematis antar variabel. Model ini dimulai oleh Ehrlich dan Holdren pada tahun 1971, dengan fokus untuk menangkap keterkaitan antara tingkat populasi, pola konsumsi, dan kualitas lingkungan yang dibangun secara khusus untuk menentukan kebijakan yang berkaitan dengan adanya peningkatan degradasi lingkungan. Hal ini terfokus kepada dampak negatif manusia terhadap lingkungan yang dibentuk dalam suatu persamaan:

$$
\mathrm{I}=\mathrm{P} \times \mathrm{A} \times \mathrm{T}
$$

di mana:

$$
\begin{aligned}
I=\text { polusi } \\
\mathrm{P}=\text { ukuran populasi } \\
\mathrm{A}=\text { tingkat konsumsi } \\
\mathrm{T}=\text { dampak polusi dari teknologi yang } \\
\\
\text { digunakan }
\end{aligned}
$$

Model ini digunakan di berbagai negara untuk mengukur penyebab utama perubahan lingkungan. Terkait dengan penurunan kapasitas daya dukung lingkungan, faktor yang berpengaruh adalah bio-fisik dan sosial-ekonomi-politik.

Sebelum menghitung kemampuan bumi menampung penduduk yang terkait dengan kesejahteraan mereka (Carnel, 2000), beberapa faktor penting lainnya yang terkait perlu diperhatikan. Faktor tersebut adalah tingkat ketersediaan dan distribusi materi untuk kesejahteraan, ketersediaan teknologi, peranan politik lembaga nasional dan internasional, pengaturan ekonomi dan demografi nasional dan internasional, kondisi lingkungan (biologi, fisik dan kimia; dan berapa variabel dan stabilitas serta untuk berapa lama, termasuk faktor nilainilai yang berlaku, cita rasa dan gaya hidup.

\section{Data dan Perspektif serta Model Analisis}

Data yang digunakan dalam makalah ini sebagian besar berasal dari Badan Pusat Statistik Kabupaten Indramayu (BPS Kabupaten Indramayu, 2003), khususnya yang berkaitan dengan jumlah nelayan dan masyarakat pesisir pada suatu wilayah kecamatan. Kecamatan yang memiliki dominasi nelayan (baik pemilik maupun buruh, dan produksi perikanan lautnya tinggi) merupakan suatu wilayah kecamatan yang diasumsikan dapat mewakili wilayah pesisir dalam wilayah Kabupaten Indramayu, sedangkan kecamatan lainnya bukan didominasi oleh nelayan.

Untuk keperluan perbandingan, diusahakan mendapatkan perkembangan dari tahun ke tahun untuk setiap parameter yang tersedia dalam data yang berasal dari buku Indramayu Dalam Angka Tahun 2003. Jika tidak tersedia data yang bersifat serial, diusahakan mendapatkan data dan atau informasi tambahan dari laporan kajian dan atau hasil riset yang berkaitan dengan halhal yang dikaji, baik pada tingkat nasional maupun yang berlaku umum terkait dengan sumberdaya lahan/perairan di wilayah pesisir. Untuk hal-hal tertentu dilakukan pembandingan dengan wilayah kecamatan lainnya dalam wilayah Kabupaten Indramayu yang penduduknya didominasi oleh petani, yaitu Kecamatan Haurgeulis, Cikedung, Widasari, Kertasemaya, dan Anjatan.

Perspektif yang digunakan dalam tulisan ini adalah perspektif kombinasi. Perspektif kombinasi berpandangan bahwa ada sejumlah akar penyebab degradasi lingkungan yang memainkan peranan pada suatu area yang tetap sebagaimana yang dikemukakan oleh Orians \& Skurmanich 
(1997). Dalam makalah ini, kemiskinan yang terdapat pada masyarakat di wilayah merupakan suatu area yang tetap yang memainkan peranan penting dalam mengkaji bagaimana tekanan penduduk di wilayah pesisir terhadap lingkungan dan sumberdaya lahan/perairan. Setelah diidentifikasi, dapat dikemukakan bagaimana penanganannya dari aspek kependudukan.

Tekanan terhadap lingkungan dan sumberdaya lahan/perairan di wilayah pesisir terkait pula dengan adanya hubungan sosial, baik sesama masyarakat pesisir maupun antara masyarakat pesisir dengan masyarakat di luar wilayah pesisir. Misalnya adalah bagaimana terbentuknya hubungan sosial antara masyarakat pesisir sebagai buruh tambak udang/ikan terhadap pemilik modal yang biasanya berada di wilayah perkotaan (bukan wilayah pesisir). Termasuk di dalamnya adalah yang mengakibatkan adanya distorsi ekonomi, misalnya penentuan harga input dan output dalam proses produksi yang sebagian besar ditentukan oleh pemilik modal dalam suatu budidaya udang/ikan sistem tambak.

Di samping itu, tekanan penduduk di wilayah pesisir harus dibarengi dengan kebijakan pemerintah yang berpihak pada masyarakat pesisir yang miskin. Kebijakan penanganan polusi misalnya yang selama ini sebagian masyarakat masih menganggap bahwa wilayah pesisir adalah tempat buangan sampah harus segera dihilangkan. Teknologi yang digunakan pun dalam pengelolaan wilayah pesisir belum banyak mendukung kondisi yang kondusif untuk wilayah pesisir, baik penataan lingkungan maupun penanganan terhadap tanaman yang ada di wilayah pesisir terutama mangrove.

Analisis tekanan penduduk di wilayah pesisir terhadap lingkungan dan sumber daya lahan/perairan menggunakan model POET (Orians \& Skurmanich, 1997). Dalam tulisan ini, $\mathrm{P}$ adalah jumlah penduduk pesisir baik nelayan, pembudidaya ikan, maupun pedagang, pengolah ikan ataupun masyarakat lain di wilayah pesisir. O adalah organisasi yang terdapat di wilayah pesisir yang terkait dengan kehidupan masyarakat pesisir terutama pemanfaatan sumber daya lahan/perairan. E adalah lingkungan yaitu kondisi sumberdaya lahan (mangrove) dan perairan (pantai dan laut) yang dimanfaatkan penduduk pesisir sebagai sumber nafkah (penangkapan dan atau budi daya ikan) serta lingkungan pemukiman, dan T adalah teknologi yang terkait dengan pemanfaatan sumberdaya lahan/perairan di wilayah pesisir dan laut terutama teknologi penangkapan ikan.

Model POET menjelaskan hubungan penduduk di wilayah pesisir dengan kondisi lingkungan dan sumberdaya lahan/perairan yang ada di sekitar wilayah pesisir tersebut, pemanfaatan sumberdaya lahan/perairan tersebut serta teknologi yang digunakan. Teknologi yang digunakan menggambarkan apakah teknologi tersebut bersifat desktruktif terhadap sumberdaya lahan/ perairan, dan sebaliknya dilihat pula bagaimana interaksi antara penduduk dan lingkungan dalam pandangan dua arah, yaitu pengaruh manusia terhadap lingkungan dan sebaliknya.

\section{PENDUDUK, KEMISKINAN DAN FAKTOR DEMOGRAFI}

\section{Pertumbuhan dan Kemiskinan Penduduk}

Tekanan penduduk terhadap lingkungan dan sumberdaya perairan, pertama-tama akan terlihat bagaimana pertumbuhan penduduk terjadi dan bagaimana kondisi kesejahteraannya yang tergambar dari kondisi kemiskinan yang dialami penduduk 
tersebut. Jumlah penduduk akhir tahun pada wilayah pesisir Kabupaten Indramayu, Jawa Barat tercantum pada Tabel 1.

Pada lima wilayah kecamatan yang mewakili daerah pesisir di Kabupaten Indramayu, penduduk tumbuh dengan laju 0,79-2,58\% per tahun selama 1999-2003. Laju pertumbuhan tertinggi terdapat pada Kecamatan Indramayu, yaitu suatu wilayah kecamatan yang menjadi ibukota kecamatan sekaligus ibukota kabupaten. Di samping itu, jika dilihat secara nasional, perkembangan masyarakat yang memanfaatkan sumber daya perairan laut dan sumber daya lahan pesisir (pantai) terlihat semakin meningkat (Tabel 2).

Tabel 2 memberikan indikasi bahwa selama 2001-2004 terdapat kecenderungan pertambahan jumlah pembudidaya ikan rata- rata sebesar $16,80 \%$ untuk budidaya laut dan 7,39\% untuk budidaya payau (tambak) Di lain pihak, kemiskinan penduduk, sebagai suatu area yang tetap dalam mengkaji masalah tekanan penduduk terhadap lingkungan dan sumber daya perairan terlihat pada Tabel 3.

Tabel 3 menggambarkan bahwa jumlah KK miskin di wilayah pesisir dalam Kabupaten Indramayu berkisar 33,51$72,15 \%$ atau rata-rata $51,42 \%$. Nilai ratarata ini masih lebih sedikit jika dibandingkan dengan jumlah rata-rata KK miskin untuk keseluruhan masyarakat di Kabupaten Indramayu yang mencapai $51,94 \%$ per kecamatan. Hal ini berarti bahwa lebih dari separuh KK penduduk di wilayah pesisir berada dalam kondisi miskin. Kemiskinan inilah yang menjadi area yang tetap dalam mengkaji bagaimana adanya tekanan

Tabel 1. Jumlah penduduk di kecamatan yang mewakili wilayah pesisir dalam Kabupaten Indramayu

Table 1. Number of people in subdistric representing coastal area in District Indramayu

\begin{tabular}{ccccc}
\hline \multirow{2}{*}{ No. } & $\begin{array}{c}\text { Kecamatan/ } \\
\text { Sub-district }\end{array}$ & $\mathbf{1 9 9 9}$ & $\mathbf{J u m l a h}$ penduduk/Number of people & $\begin{array}{c}\text { Pertumbuhan per tahun/ } \\
\text { Growth per year }(\%)\end{array}$ \\
\cline { 3 - 4 } 1. & Juntinyuat & 81.193 & 84.889 & 1,14 \\
2. & Indramayu & 97.584 & 107.617 & 2,58 \\
3. & Cantigi & $\left.22.235^{*}\right)$ & 22.934 & 0,79 \\
4. & Kandang Haur & 80,17 & 83.213 & 0,95 \\
5. & Sukra & 86.966 & 91.969 & 1,44 \\
\hline \multicolumn{4}{r}{} \\
\hline
\end{tabular}

Keterangan: *)data tahun 2001 (kecamatan pemekaran)

Tabel 2. Perkembangan jumlah rumah tangga pembudidaya ikan di perairan laut dan lahan tambak

Table 2. Development of household number of fish culture in marine and aera brackishwater pond

\begin{tabular}{llccccc}
\hline No. & $\begin{array}{c}\text { Budi daya ikanl } \\
\text { Fish culture }\end{array}$ & 2001 & 2002 & 2003 & 2004 & $\begin{array}{c}\text { Perkembangan per th } \\
\text { IDevelopment per yr (\%) }\end{array}$ \\
\hline 1. Budi daya laut & 23.455 & 23.450 & 29.189 & 35.835 & 16,80 \\
2. Budi daya payau (tambak) & 190.872 & 193.877 & 196.443 & 230.651 & 7,39 \\
\hline
\end{tabular}

Sumber/source: Direktorat Jenderal Perikanan Budidaya, 2005/Directorate General for Culture Fisheries (BBRSEKP, 2006) 
penduduk di wilayah pesisir ini terhadap lingkungan dan sumber daya lahan/perairan di wilayah Kabupaten Indramayu. Sutau hal diperlukan dalam membedah kemiskinan ini ditinjau dari aspek kependudukan adalah dengan cara mengkaji beberapa faktor demografi.

Namun demikian, beberapa hasil penelitian juga mengemukakan hal yang serupa, meskipun tidak dimasukan aspek kependudukan. Menurut Sumodiningrat (2005), terdapat beberapa faktor penyebab kemiskinan yang dikemukakan oleh orang miskin sendiri yaitu ketidakberdayaan, keterkucilan, kekurangan materi, kelemahan fisik, kerentanan, dan sikap atau perilaku. Faktor ketidakberdayaan meliputi faktor yang keberadaannya di luar kendali masyarakat miskin. Contohnya adalah ketersediaan lapangan kerja, tingkat biaya/ harga (baik barang konsumsi, sarana produksi maupun harga jual produksi), kebijakan pemerintah, sistem adat, dan lilitan hutang. Dari aspek materi adalah kepemilikan atau tidak memiliki berbagai macam aset seperti rumah, tanah, modal kerja, warisan, serta rendahnya penghasilan karena upah atau hasil panen rendah. Selain ketidakberdayaan, kelompok faktor materi ini merupakan penyebab kemiskinan yang dominan. Faktor keterkucilan berkaitan dengan hambatan fisik dan nonfisik dalam mengakses kesempatan meningkatkan kesejahteraan. Dalam hal ini, antara lain mencakup aspek lokasi yang terpencil, buruknya prasarana transportasi, rendahnya tingkat pendidikan dan keterampilan, tidak ada atau kurangnya akses terhadap kredit, pendidikan, kesehatan, dan air bersih.

Kondisi kesehatan, kemampuan bekerja, kurang makan dan kurang gizi, dan masalah sanitasi merupakan elemen kelompok faktor kelemahan fisik. Pada umumnya kondisi kesehatan yang buruk dianggap lebih penting sebagai penyebab kemiskinan dibandingkan dengan faktor ketidakmampuan (dalam arti keterampilan) bekerja. Kelompok faktor kerentanan mencerminkan ketidakstabilan atau guncangan yang dapat menyebabkan turunnya tingkat kesejahteraan. Di dalamnya mencakup masalah produksi dan bencana alam.

Faktor yang digolongkan dalam kelompok sikap dan perilaku adalah berupa kebiasaan buruk atau sikap yang cenderung menyebabkan turunnya tingkat

Tabel 3. Jumlah KK, jumlah KK Miskin, dan \% KK Miskin di daerah kecamatan yang mewakili wilayah pesisir dalam Kabupaten Indramayu

Table 3. Number of hausehold (KK), unwalfare people (number and \%) in subdistrict area representing coastal area in District Indramayu

\begin{tabular}{llccc}
\hline No & $\begin{array}{c}\text { Kecamatan/ } \\
\text { Sub-district }\end{array}$ & $\begin{array}{c}\text { Jumlah KKI } \\
\text { Number of } \\
\text { hausehold }\end{array}$ & $\begin{array}{c}\text { Jumlah KK Miskin } \\
\text { (Pra Sejahtera dan } \\
\text { Sejahtera I)/ } \\
\text { Unwalfare people } \\
\text { number }\end{array}$ & $\begin{array}{c}\text { Perkembangan/ } \\
\text { Development } \\
\text { (\%) }\end{array}$ \\
\hline 1 & Juntinyuat & 25.279 & 8.471 & 33,51 \\
2 & Indramayu & 27.318 & 13.398 & 49,04 \\
3 & Cantigi & 6.305 & 4.549 & 72,15 \\
4 & Kandang Haur & 22.695 & 14.089 & 62,08 \\
5 & Sukra & 24.597 & 9.910 & 40,29 \\
\hline \multicolumn{5}{r}{ Rata-Rata 5 Kecamatan Wilayah Pesisir } \\
\hline \multicolumn{4}{r}{ Rata-Rata Kecamatan di Kabupaten Indramayu } \\
\hline
\end{tabular}


kesejahteraan atau menghambat kemajuan. Contohnya adalah kurangnya upaya untuk bekerja, tidak efisien dalam mengatur uang, masalah ketidakharmonisan keluarga, serta bahkan ada pula kebiasaan berjudi dan atau mabuk-mabukan. Faktor-faktor penyebab kemiskinan tersebut tidak berdiri sendiri, melainkan saling terkait, dan merupakan rangkaian sebab akibat.

\section{Faktor Demografi}

Tingginya pertumbuhan penduduk di wilayah pesisir diakibatkan oleh beberapa faktor demografi, antara lain yang terkait dengan angka kelahiran dan besarnya migrasi penduduk ke wilayah tersebut serta ketersediaan sarana dan prasarana kesehatan di wilayah tersebut. Pada setiap wilayah kecamatan, rata-rata tingkat kelahiran adalah 1.237 orang dan rata-rata tingkat kematian 545 orang (Tabel 4). Dengan demikian terdapat selisih relatif besar untuk rata-rata per kecamatan di wilayah pesisir (692 orang per kecamatan). Pendatang (imigrasi) yang tinggi juga mendorong terjadinya peningkatan jumlah penduduk, yaitu rata-rata 2.240 orang per kecamatan, sementara perpindahan (emigrasi) hanya 320 orang per kecamatan. Dalam kaitannya dengan perpindahan penduduk (population movement), termasuk migrasi dari satu desa atau kecamatan ke desa atau kecamatan lainnya sebagaimana terjadi di wilayah Kabupaten Indramayu perlu memperhatikan beberapa permasalahan yang terkait dengan kesehatan lingkungan dan penularan penyakit. Menurut Yusuf (2000), jika ada perpindahan penduduk, perlu diperhatikan beberapa masalah kesehatan terutama mengenai adanya penyakit-penyakit yang berbeda di daerah asal dan yang didatangi. Beberapa kemungkinan yang dikemukakan adalah:

a. Penduduk baru membawa penyakit yang tidak ada di daerah baru itu - dari daerah asal ke daerah baru. Penduduk setempat di daerah pemukiman baru tidak mempunyai kekebalan terhadap penyakit tersebut, sehingga penduduk asli akan terjangkit penyakit baru. Contohnya adalah penyakit campak yang menimpa orang-orang yang belum mengenal penyakit tersebut dan tidak mempunyai kekebalan tubuh terhadap penyakit tersebut.

b. Di daerah pemukiman baru ada penyakit yang tidak ada di daerah asal penduduk baru. Di sini penduduk baru tidak kebal dan mudah terserang oleh penyakit yang ada di daerah baru. Sebagai contoh adalah malaria.

c. Pendatang ke daerah baru kemudian kembali ke daerah asal dan membawa penyakit. Hal ini banyak yang terjadi dengan penyakit malaria.

Tabel 4. Mutasi penduduk di kecamatan yang mewakili wilayah pesisir dalam Kabupaten Indramayu

Table 4. People mutation in sub-district representing coastal area in District Indramayu

\begin{tabular}{llcccc}
\hline No. & $\begin{array}{c}\text { Kecamatan/ } \\
\text { Sub-district }\end{array}$ & $\begin{array}{c}\text { Lahir/Natality } \\
\text { (orang) }\end{array}$ & $\begin{array}{c}\text { Mati/Mortality } \\
\text { (orang) }\end{array}$ & $\begin{array}{c}\text { Datangl } \\
\text { Emigration } \\
\text { (orang) }\end{array}$ & $\begin{array}{c}\text { Pindah/Imigration } \\
\text { (orang) }\end{array}$ \\
\hline 1. Juntinyuat & 1.345 & 591 & 2.446 & 226 \\
2. Indramayu & 1.702 & 750 & 2.181 & 358 \\
3. Cantigi & 363 & 160 & 518 & 274 \\
4. Kandang Haur & 1.318 & 580 & 1.869 & 319 \\
5. Sukra & 1.456 & 641 & 4.186 & 421 \\
\hline & Rata-rata & $\mathbf{1 . 2 3 7}$ & $\mathbf{5 4 5}$ & $\mathbf{2 . 2 4 0}$ & $\mathbf{3 2 0}$ \\
\hline
\end{tabular}


Tingginya tingkat kelahiran ditunjang pula dengan kondisi pencapaian akseptor Keluarga Berencana (KB) aktif dibandingkan dengan Pasangan Usia Subur (PUS) yang rata-rata masih rendah jika dibandingkan dengan wilayah kecamatan lainnya yang bukan wilayah pesisir (Tabel 5). Rata-rata peserta KB aktif dibandingkan dengan PUS adalah $70,29 \%$ untuk wilayah kecamatan pesisir, sementara untuk wilayah non pesisir adalah $71,24 \%$.

Rata-rata sebuah fasilitas kesehatan tersedia untuk 22.220 penduduk (Tabel 6 ). Di lain pihak, pada wilayah kecamatan pesisir seorang guru rata-rata harus memberikan pendidikan pada 15 orang (Tabel 7). Nilai ini masih memungkinkan bagi seorang guru untuk memberikan pengajaran secara maksimal terhadap muridnya. Namun demikian, masih terdapat penduduk usia sekolah yang berada dalam kondisi putus sekolah atau bahkan buta huruf (Tabel 8). Sebesar 21,69\% penduduk usia sekolah di kecamatan wilayah pesisir merupakan generasi yang putus sekolah dan buta huruf. Kondisi ini berpengaruh terhadap perkembangan generasi muda di wilayah pesisir Kabupaten Indramayu di masa depan.

\section{KONDISI LINGKUNGAN DAN SUMBER DAYALAHAN/PERAIRAN}

\section{Kondisi Lingkungan Pemukiman}

Dari segi lingkungan, masalah pemukiman adalah masalah penduduk. Hal ini didasarkan atas pertimbangan bahwa ketika jumlah manusia terbatas dan kebutuhan akan lingkungan tidak merupakan hal yang menjadi persaingan. Sebaliknya, lingkungan pemukiman akan menjadi kebutuhan utama penduduk pada saat penduduk di suatu wilayah menjadi lebih padat. Hal ini misalnya terlihat di wilayah pesisir di Kecamatan Kandang Haur, Kabupaten Indramayu (di Desa Eretan Wetan) yang menunjukkan pemukiman masyarakat nelayan sangat padat. Jarak satu rumah dengan rumah yang lainnya sangat dekat, bahkan kurang dari satu meter. Jalan desa juga kecil dan suasana pembuangan air hasil limbah rumah tangga pun tidak lancar, bahkan tempat pembuangan sampahpun hanya dikumpulkan di sekitar lingkungan pemukiman yang berdekatan daerah laut.

Berdasarkan kondisi lingkungan pemukiman yang dikemukakan bahwa pada

Tabel 5. Pencapaian akseptor Keluarga Berencana (KB) aktif dan Pasangan Usia Subur (PUS) menurut kecamatan yang mewakili wilayah pesisir dalam Kabupaten Indramayu

Table 5. Performance of family planning acceptor and fertile couple according district representing coastal area in District Indramayu

\begin{tabular}{llccc}
\hline No. & $\begin{array}{c}\text { Kecamatanl } \\
\text { Sub-district }\end{array}$ & $\begin{array}{c}\text { Pasangan usia subur } \\
\text { (PUS)/ Fertile couple }\end{array}$ & $\begin{array}{c}\text { Peserta KB aktifl } \\
\text { Family planning } \\
\text { active member }\end{array}$ & $\begin{array}{c}\text { Persentase KB aktif } \\
\text { terhadap PUSI } \\
\text { Percentage of KB to PUS }\end{array}$ \\
\hline 1. Juntinyuat & 16.785 & 11.870 & 70,72 \\
2. & Indramayu & 20.290 & 14.310 & 70,53 \\
3. & Cantigi & 5.237 & 3.691 & 70,48 \\
4. & Kandang Haur & 16.960 & 11.916 & 70,26 \\
5. & Sukra & 18.864 & 13.105 & 69,47 \\
\hline \multicolumn{4}{r}{ Rata-rata 5 Kecamatan Wilayah Pesisir } \\
\hline
\end{tabular}


Tabel6. Jumlah penduduk dan ketersediaan fasilitas kesehatan per jumlah penduduk di kecamatan yang mewakili wilayah pesisir dalam Kabupaten Indramayu

Table 6. Number of people and availbility of health facility per people in sub-district representing coastal area in District Indramayu

\begin{tabular}{|c|c|c|c|c|}
\hline No & $\begin{array}{l}\text { Kecamatan/ } \\
\text { Sub-district }\end{array}$ & $\begin{array}{l}\text { Jumlah Penduduk/ } \\
\text { People number }\end{array}$ & $\begin{array}{c}\text { Jumlah Puskesmas*) } \\
\text { Community Health } \\
\text { Center }\end{array}$ & $\begin{array}{c}\text { Rasio Penduduk per } \\
\text { Puskesmas } / \\
\text { Ratio of people per } \\
\text { Community Health Center }\end{array}$ \\
\hline 1 & Juntinyuat & 84.889 & 2 & 42.445 \\
\hline 2 & Indramayu & 107.617 & 6 & 17.936 \\
\hline 3 & Cantigi & $\left.22.934^{* *}\right)$ & 5 & 4.589 \\
\hline 4 & Kandang Haur & 83.213 & 3 & 27.738 \\
\hline 5 & Sukra & 91.969 & 5 & 18.394 \\
\hline \multicolumn{4}{|c|}{ Rata-Rata 5 Kecamatan Wilayah Pesisir } & 22.220 \\
\hline
\end{tabular}

Tabel 7. Jumlah murid, guru dan rasio murid terhadap guru di kecamatan yang

7. Pupil and teacher number and ratio of pupil to teacher in sub-district representing coastal area in District Indramayu

\begin{tabular}{llccc}
\hline No & $\begin{array}{c}\text { Kecamatan/ } \\
\text { Sub-district }\end{array}$ & $\begin{array}{c}\text { Jumlah Murid/ } \\
\text { Pupil number }\end{array}$ & $\begin{array}{c}\text { Jumlah Guru/ } \\
\text { Teacher number }\end{array}$ & $\begin{array}{c}\text { Rasio Murid Terhadap } \\
\text { Guru/ Ratio of pupil } \\
\text { to teacher }\end{array}$ \\
\hline 1 & Juntinyuat & 1.787 & 115 & 16 \\
2 & Indramayu & 653 & 35 & 19 \\
3 & Cantigi & $0^{*}$ ) & $\left.0^{*}\right)$ & - \\
4 & Kandang Haur & 314 & 23 & 14 \\
5 & Sukra & 355 & 33 & 11 \\
\hline \multicolumn{2}{c}{ Rata-Rata 5 Kecamatan Wilayah Pesisir } \\
\hline \multicolumn{2}{l}{ Keterangan: ")tidak ada data (kecamatan pemekaran). }
\end{tabular}

Tabel 8. Jumlah penduduk usia sekolah dan rasio penduduk putus sekolah di kecamatan yang mewakili wilayah pesisir dalam Kabupaten Indramayu Table 8. Educated age people number and ratio of uncertified educated people in sub-district in District Indramayu

\begin{tabular}{|c|c|c|c|c|c|}
\hline No & $\begin{array}{l}\text { Kecamatan/ } \\
\text { Sub-district }\end{array}$ & $\begin{array}{l}\text { Penduduk Usia } \\
\text { 7-18 Tahun/ } \\
\text { People above } \\
7-18 \text { year old }\end{array}$ & $\begin{array}{c}\text { Penduduk Putus } \\
\text { Sekolah/ } \\
\text { Uncertified } \\
\text { educated people }\end{array}$ & $\begin{array}{c}\text { Penduduk Buta } \\
\text { Huruf } / \\
\text { Uneducated } \\
\text { people }\end{array}$ & $\begin{array}{l}\text { \% Putus Sekolah } \\
\text { dan Buta Huruf/ } \\
\text { Percentage of } \\
\text { uncertified } \\
\text { educated people } \\
\text { and uneducated }\end{array}$ \\
\hline 1 & Juntinyuat & 20.879 & 187 & 1.675 & 8,92 \\
\hline 2 & Indramayu & 27.174 & 93 & 1.793 & 6,94 \\
\hline 3 & Cantigi & 5.830 & 10 & 3.479 & $\left.59,85^{\star}\right)$ \\
\hline 4 & Kandang Haur & 21.393 & 270 & 4.977 & 24,53 \\
\hline 5 & Sukra & 22.329 & 317 & 1.511 & 8,19 \\
\hline \multicolumn{5}{|c|}{ Rata-Rata 5 Kecamatan Wilayah Pesisir } & 21,69 \\
\hline
\end{tabular}

Keterangan: ")kecamatan pemekaran. 
hakekatnya kurang bersih dan tidak teratur, sehingga pembuangan air juga tidak lancar. Kondisi demikian dapat memberikan kesempatan perkembangan penyakit yang terkait dengan lingkungan yang buruk sebagai media perkembangbiaknya. Kondisi lingkungan sangat besar pengaruhnya terhadap kesehatan manusia. Di dalam lingkungan yang sesuai, penyebab penyakit dapat dipelihara dan ditularkan dari manusia ke manusia, dari hewan ke manusia, dari hewan ke hewan atau dari manusia ke hewan.

Terkait dengan kesehatan lingkungan, Yusuf (2000) mengemukakan bahwa di dalam alam yang ditempati manusia dan hewan, selalu ada penyebab penyakit manusia dan hewan, karena setiap saat ada manusia atau hewan yang sakit dan mengeluarkan penyebab penyakit dari badannya. Penyebab penyakit tersebut dapat berupa bahan fisik maupun kimia dan berbagai macam organisme seperti virus, bakteri, fungus, protozoa, cacing dan serangga, yang dapat ditularkan baik secara langsung maupun tidak langsung dengan perantaraan udara, air, tanah, dan hewan atau tumbuh-tumbuhan.

Dalam kondisi lingkungan pemukiman masyarakat pesisir seperti yang dikemukakan di atas, penularan penyakir sangat memungkinkan melalui air karena jika kualitas air tidak diperhatikan, maka air dapat menjadi sumber penyebab penyakit. Hampir semua jenis organisme penyebab penyakit dapat ditemukan dalam air. Banyak penyakit menular bersumber pada air (water borne diseases). Contoh klasik penyakit bakteri yang bersumber pada air (water borne diseases) ialah typhoid, disentri, dan kolera. Air yang tercemar oleh ekskreta tikus dapat menularkan leptospirosis yang disebabkan oleh leptospira. Juga penyakit jamur dapat ditularkan melaui air, dan bentuk-bentuk infektif protozoa seperti Entamoeba histolytica dan cacing-cacing perut dapat ditemukan dalam air pula.

Air selain dapat menularkan penyakit secara langsung, dapat juga menjadi tempat perindukan (habitat) berbagai penyebar (vector) dan sumber (hospes reservoir) penyakit (Yusuf, 2000). Dikemukakan pula bahwa berbagai serangga memerlukan air untuk tumbuh dan berkembangbiak seperti nyamuk yang dapat menularkan berbagai macam penyakit. Penyakit virus yang banyak ditakuti menyerang anak-anak yang sehat adalah dengue hemorrhagic fever (demam berdarah). Penyakit ini ditularkan oleh nyamuk Aedes aegypti yang dapat berkembangbiak dalam air di sekitar rumah.

Segala tempat yang dapat digenangi air pada musim hujan dapat dipakai sebagai tempat perinduknya. Penyakit yang ditularkan oleh nyamuk yang disebabkan oleh protozoa adalah malaria. Berbagai macam nyamuk penyebab malaria dapat berkembangbiak dalam bermacam kualitas air. Anopheles sundaicus memerlukan air payau di tepi pantai sebagai tempat perindukannya. Namun demikian, nyamuk vector malaria ada pula yang memerlukan air bersih yang mengalir.

\section{Kondisi Sumberdaya Lahan/Perairan}

Kondisi sumberdaya lahan/perairan yang digambarkan dalam hal ini adalah kondisi produksi perikanan yang bersumber dari beberapa daerah perairan, yaitu perairan Maluku-Papua, Selat Malaka dan Selatan Sulawesi serta Utara Jawa. Total produksi dari keempat daerah perairan laut ini mencapai 40-60\% total produksi seluruh perairan selama 2001-2003 (Tabel 9).

Tabel 10 menunjukkan bahwa terdapat peningkatan produksi hasil budidaya laut 
dan budidaya tambak yang tajam jika dibandingkan antara tahun 2002 dan 2005. Hal ini berarti bahwa peningkatan produksi budidaya laut dan tambak tidak akan dapat dicapai dengan hanya mengandalkan prinsip intensifikasi budidaya, tetapi juga terjadi ekstensifikasi usaha atau perluasan areal budidaya. Artinya, perluasan lahan budidaya dilakukan untuk upaya peningkatan produksi. Hal ini merupakan suatu tekanan adanya permintaan yang direspon oleh masyarakat pesisir sesuai dengan pandapat Alcamo et al. (2007) bahwa perubahan pada jasa ekologi akan mempengaruhi penggerak perubahan dan sering dijumpai kombinasi penggerak yang bersinergi. Artinya, jasa ekologi perairan laut dalam menghasilkan sumberdaya perikanan atau pemanfaatan lahan mangrove untuk tambak akan mempengaruhi manusia sebagai penggerak perubahan dan sebaliknya.

\section{KONDISI PENGORGANISASIAN}

Pengorganisasian yang dimaksud adalah pengorganisasian yang dapat berpengaruh terhadap pengembangan berbagai aspek pada suatu wilayah. Dalam hal wilayah pesisir misalnya bagaimana hubungan sosial antar masyarakat, bagaimana organisasi ekonomi dan dampaknya terhadap masyarakat setempat serta bagaimana pengorganisasian perlindungan terhadap lingkungan kaitannya dengan upaya untuk mengontrol pertumbuhan penduduk di wilayah pesisir. Berkaitan dengan pengorganisasian ini, dengan kata lain dapat dinyatakan bahwa bagaimana pengembangan wilayah pesisir yang dilakukan oleh pemerintah melalui berbagai program pembangunan, baik yang dilaksanakan melalui Departemen Kelautan dan Perikanan maupun departemen lainnya yang terkait, diperlukan pengorganisasian.

Tabel 9. Produksi perikanan beberapa daerah perairan laut di Indonesia (Ton)

Table 9. Production of fisheries from some marine area of Indonesia (ton)

\begin{tabular}{ccccc}
\hline \multirow{2}{*}{ No. } & $\begin{array}{c}\text { Daerah perairan laut/ } \\
\text { Marine Areas }\end{array}$ & $\mathbf{2 0 0 1}$ & $\mathbf{2 0 0 2}$ & $\mathbf{2 0 0 3}$ \\
\cline { 3 - 5 } 1. & Maluku-Papua & 510,555 & 477,757 & 695,062 \\
2. & Utara Jawa & 812,468 & 785,202 & 754,345 \\
3. & Selat Malaka & 598,848 & 601,940 & 634,693 \\
4. Selatan Sulawesi & 465,988 & 504,428 & 539,919 \\
5. & Lainnya & $1,578,621$ & $1,704,179$ & $1,760,084$ \\
\hline & Total & $\mathbf{3 , 9 6 6 , 4 8 0}$ & $\mathbf{4 , 0 7 3 , 5 0 6}$ & $\mathbf{4 , 3 8 3 , 1 0 3}$ \\
\hline
\end{tabular}

Sumber: Statistik Perikanan Tangkap Indonesia, 2005 (BBRSE, 2006).

Tabel 10. Perkembangan produksi perikanan budidaya laut dan budidaya tambak, Tahun $2002-2005$ (Ton)

Table 10. Development of fis culture in marine waters and brackishwater, 20022005 (ton)

\begin{tabular}{lccccc}
\hline & \multicolumn{4}{c}{ Tahun/Year } & \multicolumn{1}{c}{\begin{tabular}{c} 
Kenaikan rata- \\
Katag (\%)/ \\
\cline { 2 - 6 }
\end{tabular}} \\
\cline { 2 - 6 } & $\mathbf{2 0 0 2}$ & $\mathbf{2 0 0 3}$ & $\mathbf{2 0 0 4 *}$ & $\mathbf{2 0 0 5 *}$ & $\begin{array}{c}\text { Average } \\
\text { increase }\end{array}$ \\
\hline Budidaya Laut & 234.859 & 249.242 & 420.919 & 519.200 & 23,35 \\
Budidaya Tambak & 473.128 & 501.977 & 559.612 & 643.600 & 8,48 \\
\hline
\end{tabular}

Sumber: Direktorat Jenderal Perikanan Tangkap - DKP 2005 (BBRSE, 2006).

Keterangan: *) Angka Perkiraan 
Hubungan sosial antar masyarakat di wilayah pesisir, terutama yang berkaitan dengan aspek ekonomi, banyak terjadi hubungan yang bersifat patron klien, yaitu hubungan buruh majikan, baik dalam pemanfaatan sumberdaya perairan laut (penangkapan ikan di laut) maupun pemanfaatan sumberdaya lahan (tambak). Kondisi demikian telah banyak diteliti dan hasilnya menyatakan bahwa hubungan tersebut terjadi karena kurang berfungsinya pengorganisasian terhadap masyarakat, terutama nelayan dan pembudidaya ikan di tambak (Kusnadi, 2002; Nasution et al. 2005).

Di lain pihak, beberapa wilayah yang menerima program Pemberdayaan Ekonomi Masyarakat Pesisir (PEMP) telah merasakan manfaat pengorganisasian yang dilakukan pemerintah dengan perbaikan pada aspek lembaga keuangan mikro. Hal ini misalnya terlihat pada masyarakat nelayan di desa Tambak Lekok di Kabupaten Pasuruan, Jawa Timur (Nasution et al, 2004). Namun demikian, perkembangan usaha perikanan pada wilayah pesisir di Indramayu dapat digambarkan dari perkembangan organisasi ekonomi yang ada di wilayah tersebut. Sebagai gambaran bahwa sudah mulai ada perkembangan organisasi keuangan yang dibutuhkan oleh masyarakat di wilayah Kabupaten Indramayu (Tabel 11).

KUD mina dan koperasi perikanan sebagai wadah pengorganisasian masyarakat pesisir, teruatama nelayan dan pembudidaya ikan, telah berkembang, meskipun volume usaha yang tumbuh belum sebesar koperasi lainnya seperti KUD Pangan. Kemudian, dari segi penyerapan tenaga kerja, kedua jenis koperasi perikanan tersebut juga menyerap tenaga kerja dalam jumlah yang cukup besar sebagaimana terlihat pada KUD Mina (Tabel 11).

\section{KONDISI TEKNOLOGI}

Dalam perkembangan wilayah pesisir, teknologi merupakan suatu indikator bagaimana kondisi pemanfaatan sumberdaya lahan/perairan yang dilakukan oleh penduduk di wilayah tersebut. Nelayan dan pembudidaya ikan menggunakan teknologi untuk menangkap ikan dan membudidaya ikan di tambak. Bagaimana dampaknya terhadap kondisi lingkungan sumberdaya lahan/perairan merupakan suatu hal yang perlu diperhatikan kaitannya dengan daya dukung lingkungan atau sumberdaya tersebut. Kemudian, bagaimana polusi atau teknologi yang tidak tepat dapat dicegah di dalam konteks pengembangan suatu masyarakat dalam wilayah pesisir tersebut juga merupakan upaya yang perlu diperhatikan dalam pelaksanaan pembangunan di wilayah pesisir.

Sebagai gambaran adalah perkembangan teknologi penangkapan ikan di wilayah pesisir Kabupaten Indramayu (Tabel 12). Ribuan motor tempel terdapat di wilayah tersebut, di samping ratusan kapal motor. Kondisi ini menunjukkan bahwa terdapat 318 kapal motor yang biasanya menggunakan teknologi penangkapan ikan yang tidak selektif. Artinya, alat tangkap dapat menangkap berbagai jenis dan ukuran ikan, sehingga dapat mengganggu kapasitas daya rekruitmen populasi sumberdaya ikan di wilayah tersebut.

Sebagian besar alat tangkap atau teknologi penangkapan ikan yang digunakan di wilayah pesisir Kabupaten Indramayu tidak selektif. Alat tangkap atau teknologi penangkapan tersebut terutama berupa pukat kantong, pukat pantai, gill-net dan pukat cincin. Alat tangkap yang terakhir berupa pukat cincin yang menggunakan 
Tabel 11. Jumlah koperasi dan volume usaha menurut jenis koperasi dalam Kabupaten Indramayu

Table 11. Number of cooperation and business volume according kind of cooporation in District Indramayu

\begin{tabular}{llccc}
\hline No $\begin{array}{c}\text { Jenis Koperasi/ } \\
\text { kind of cooporation }\end{array}$ & $\begin{array}{c}\text { Jumlah Koperasi } \\
\text { (buah)/ } \\
\text { Cooperation number }\end{array}$ & $\begin{array}{c}\text { Volume Usaha } \\
\text { (O00 Rupiah)/ } \\
\text { business volume }\end{array}$ & $\begin{array}{c}\text { Tenaga Kerja } \\
\text { (Orang)/ } \\
\text { Labour }\end{array}$ \\
\hline 1 & KUD Pangan & 44 & 105.404 .714 & 248 \\
2 & KUD Mina & 9 & 58.990 .996 & 188 \\
3 & Kop Karyawan & 48 & 2.845 .380 & 43 \\
4 & Kop Pontren & 61 & 6.445 .568 & 55 \\
5 & Kop Hasil Hutan & 100 & 13.723 .914 & 75 \\
6 & Kop Serba Usaha & 131 & 1.822 .847 & 31 \\
7 & Kop Pedagang Kecil & 25 & 349.492 & 7 \\
8 & Kop Perikanan & 17 & 132.795 & 6 \\
9 & Kop Pasar & 17 & 219.223 & 125 \\
10 & Kop Jasa & 15 & 1.740 .568 & 45 \\
11 & Kop Kerajinan & 10 & 6.314 .222 & 34 \\
12 Kop Pemuda & 15 & 257.786 & 11 \\
\hline
\end{tabular}

Tabel 12. Jumlah motor tempel dan kapal motor penangkap ikan di kecamatan yang mewakili wilayah pesisir dalam Kabupaten Indramayu

Table 12. Number of boat and fishing boat in district representing coastal area in District Indramayu

\begin{tabular}{|c|c|c|c|c|}
\hline \multirow[b]{2}{*}{ No } & \multirow{2}{*}{$\begin{array}{l}\text { Kecamatan/ } \\
\text { Sub-district }\end{array}$} & \multicolumn{3}{|c|}{ Jenis Kapal Penangkap Ikan/Kind of fishing vessel } \\
\hline & & $\begin{array}{c}\text { Motor Tempel/ } \\
\text { Boat }\end{array}$ & $\begin{array}{l}\text { Kapal Motorl } \\
\text { Boat vessel }\end{array}$ & $\begin{array}{l}\text { Jumlah/ } \\
\text { Number }\end{array}$ \\
\hline 1 & Juntinyuat & 1.309 & 125 & 1.434 \\
\hline 2 & Indramayu & 551 & 85 & 636 \\
\hline 3 & Cantigi & 408 & 2 & 410 \\
\hline 4 & Kandang Haur & 1.098 & 106 & 1.203 \\
\hline 5 & Sukra & 333 & 0 & 333 \\
\hline & Jumlah & 3.699 & 318 & 4.017 \\
\hline
\end{tabular}

penggerak berupa kapal motor dengan berbagai ukuran. Secara keseluruhan, perkembangan teknologi penangkapan ikan yang dapat dilihat berdasarkan perkembangan perahu/kapal perikanan berbagai ukuran diperlihatkan pada Tabel 13. Tabel 13 memberikan petunjuk bahwa terjadi peningkatan yang besar pada setiap jenis perahu/kapal motor perikanan di Indonesia selama tahun 2000-2004. Hal ini memberikan gambaran bahwa perijinan kapal motor terutama yang berukuran besar meningkat drastis, bahkan mencapai ratarata $52 \%$ untuk ukuran $30-50$ GT.

Dengan demikian, suatu hal yang mengakibatkan kondisi masyarakat di wilayah pesisir, termasuk di Kabupaten Indramayu berada dalam kondisi miskin atau prasejahtera sebagaimana dikemukakan di awal makalah ini antara lain adalah sebagai akibat ketatnya persaingan dalam memanfaatkan sumberdaya perairan, sebagai akibat pertumbuhan penduduk 
Tabel 13. Perkembangan perahu/kapal perikanan menurut kategori Table 13. Development of fishing boat/vesel according its catagory

\begin{tabular}{lccccc}
\hline $\begin{array}{c}\text { Jenis dan Ukuran Kapall } \\
\text { Kind and size of vessel }\end{array}$ & $\mathbf{2 0 0 0}$ & $\mathbf{2 0 0 1}$ & $\mathbf{2 0 0 2}$ & $\mathbf{2 0 0 3}$ & $\begin{array}{c}\text { Kenaikan } \\
\text { (\%)/ } \\
\text { Increase }\end{array}$ \\
\hline Perahu Motor Tempel & 121,022 & 120,054 & 130,185 & 158,411 & 4.89 \\
Kapal Motor : & 97,669 & 106,753 & 111,034 & 119,837 & 5.41 \\
KM < 5 GT & 65,897 & 70,925 & 74,292 & 79,218 & 3.94 \\
KM 5 - 10 GT & 19,460 & 22,641 & 20,208 & 24,358 & 5.34 \\
KM 10 - 20 GT & 5,599 & 6,006 & 5,866 & 5,764 & 7.24 \\
KM 20 - 30 GT & 2,974 & 3,008 & 3,382 & 3,131 & 11.9 \\
KM 30 - 50 GT & 1,543 & 781 & 2,685 & 2,338 & 52.38 \\
KM 50 - 100 GT & 1,129 & 1,602 & 2,430 & 2,698 & 24.04 \\
KM 100 - 200 GT & 741 & 1,295 & 1,612 & 1,731 & 24.42 \\
KM > 200 GT & 326 & 495 & 559 & 599 & 17.05 \\
\hline
\end{tabular}

Sumber: Direktorat Jenderal Perikanan Tangkap - DKP, 2005 (BBRSE, 2006).

yang juga tinggi. Sebaliknya, pertumbuhan penduduk yang tinggi juga mengakibatkan adanya persaingan yang juga tinggi dalam memanfaatkan sumberdaya lahan / perairan di wilayah pesisir tersebut.

\section{KESIMPULAN}

Dalam mengkaji tekanan penduduk terhadap lingkungan dan sumberdaya lahan atau perairan di wilayah pesisir dapat digunakan pendekatan kependudukan. Namun demikian, untuk memahami hal-hal yang berkaitan dengan kependudukan, diperlukan pengetahuan demografi. Perspektif yang dapat digunakan adalah perspektif kombinasi, yang berpandangan bahwa ada sejumlah akar penyebab degradasi lingkungan yang memainkan peranan pada suatu area yang tetap. Kemudian secara sederhana sebagai dasar analisis dapat digunakan model POET untuk mengkaji keterkaitan hubungan manusia dan lingkungan serta sumberdaya lahan / perairan.

Hasil kajian terhadap data kependudukan dan kondisi sumberdaya lahan atau perairan di wilayah kecamatan pesisir dalam Kabupaten Indramayu menunjukkan bahwa kemiskinan terdapat pada masyarakat di wilayah pesisir tersebut. Suatu hal yang mengakibatkan kondisi masyarakat di wilayah pesisir, termasuk di Kabupaten Indramayu berada dalam kondisi miskin atau prasejahtera adalah ketatnya persaingan dalam memanfaatkan sumberdaya perairan. Hal ini antara lain juga sebagai akibat keberadaan pertumbuhan penduduk yang juga tinggi. Teknologi penangkapan ikan juga bersifat merusak sumberdaya ikan di perairan laut (tidak selektif dan menggunakan kapal motor), di samping pembukaan lahan tambak yang meningkat. Salah satu akibatnya adalah terjadinya hubungan sosial yang bersifat patron klien. Di samping itu, lingkungan pemukiman yang juga tidak baik merupakan hal yang penting ditata sebagai akibat kepadatan penduduk.

\section{REKOMENDASI}

Beberapa alternatif penanganan dalam upaya pengurangan tekanan penduduk di wilayah terhadap lingkungan dan sumberdaya lahan/perairan ditinjau dari aspek kependudukan adalah dengan cara menurunkan laju pertumbuhan penduduk di kawasan tersebut. Berdasarkan kondisi 
yang terdapat di kawasan pesisir dalam Kabupaten Indramayu, upaya yang perlu dilakukan antara lain adalah penurunan tingkat kelahiran. Penurunan tingkat kelahiran ini dapat dilakukan antara lain dengan meningkatkan peserta KB aktif di kawasan tersebut terhadap PUS yang saat ini masih cukup tinggi. Kemudian, tingginya tingkat imigrasi ke wilayah pesisir saat ini dapat dikurangi dengan cara pengorganisasian kelompok nelayan dengan aktif membuat pengaturan agar sumberdaya perikanan perairan laut setempat hanya dapat dimanfaatkan oleh masyarakat lokal saja. Pembatasan izin masuk wilayah penangkapan terutama alat terhadap alat dan penangkapan yang tidak selektif dan bermotor (purse seine) dan penyediaan alternatif sumber pendapatan di luar perikanan juga akan mengurangi tekanan terhadap sumberdaya lahan / perairan di wilayah tersebut.

\section{PERSANTUNAN}

Makalah ini adalah bagian dari Kegiatan Riset yang berjudul Analisis Kebijakan Penyehatan Usaha Perikanan di Wilayah Pantura di Balai Besar Riset Sosial Ekonomi Kelautan dan Perikanan Tahun Anggaran 2005.

\section{DAFTAR PUSTAKA}

Alcamo. et al. 2007. Ekosistem dan Kesejahteraan Manusia: Suatu Kerangka Pikir untuk Penilaian. Laporan Kelompok Kerja Conceptual Framework Millenium Ecosystem Assessment. The United Nations Environment Program. http://www.kehati.or.id/pdf/SummaryMA/ INDO-NESIA.pdf Diakses tgl. 6 Juni 2007.

BBRSEKP (Balai Besar Riset Sosial Ekonomi Kelautan Perikanan). 2006. Indikator Kinerja dan Hasil Riset Sosial
Ekonomi Kelautan dan Perikanan. Badan Riset Kelautan dan Perikanan. Departemen Kelautan dan Perikanan. Jakarta.

BPS (Badan Pusat Statistik) Kabupaten Indramayu. 2003. Indramayu Dalam Angka 2003. Kerjasama BPS Kabupaten Indramayu dengan Bappeda Kabupaten Indramayu. Indramayu.

Carnell, B. 2000. Carrying Capacity. Carrying capacity_carnell.htm Sunday, May 14. 2000. Diakses tgl. 15 Agustus 2006.

Idris. I. 2003. Kebijakan dan Strategi Pengelolaan Wilayah Pesisir. Direktorat Jenderal Pesisir dan Pulau-Pulau Kecil. Departemen Kelautan dan Perikanan. Jakarta.

Kusnadi. 2002. Konflik Sosial Nelayan: Kemiskinan dan Perebutan Sumberdaya Perikanan. Penerbit LkiS. Yogyakarta. 190 pp.

Nasution, Z., T. T. Hartono, Sastrawidjaja, F. N. Priyatna, Mursidin, G. B. Aji, M. Suherman \& T. Pranaji. 2004. Riset Sosio Antropologi Dalam Rangka Pemberdayaan Masyarakat Nelayan, Laporan Teknis Kegiatan. Pusat Riset Pengolahan Produk dan Sosial Ekonomi Kelautan dan Perikanan (PRPPSEKP), Badan Riset Kelautan dan Perikanan. Departemen Kelautan dan Perikanan.

Nasution, Z., Sastrawidjaja, T. T. Hartono, F. N. Priyatna, Mursidin, G. B. Aji, \& M. Suherman. 2005. Riset Sosio Antropologi Dalam Rangka Pemberdayaan Masyarakat Nelayan, Laporan Teknis Kegiatan. Pusat Riset Pengolahan Produk dan Sosial Ekonomi Kelautan dan Perikanan (PRPPSEKP), Badan Riset Kelautan dan Perikanan. Departemen Kelautan dan Perikanan. 
Orians, C. E. \& M. Skumanich. 1997. The Population-Environment Connection. What Does It Mean for Environmental Policy? Futures Studies Unit. Office of Policy Planning and Evaluation. U.S. Environmental Protection Agency. Battelle Seattle Research Center. PO Box 5395. Seattle. WA.

Sumodiningrat. G. 2005. Peran Departemen Kelautan dan Perikanan dalam penanggulangan kemiskinan melalui kredit mikro. Makalah disampaikan dalam Diskusi Upaya Perumusan Langkah Bersama Penanggulangan Kemiskinan Nelayan yang diselenggarakan oleh Badan Riset Kelautan dan Perikanan. Departemen Kelautan dan Perikanan. Jakarta 24 Agustus 2005.

Yusuf, M. 2000. Pendidikan Kependudukan \& Etika Lingkungan. Lembaga Studi dan Inovasi Pendidikan. Yogyakarta. 